\title{
The Clinicopathological Significance of Epigenetic Silencing of VHL Promoter and Renal Cell Carcinoma: A Meta-Analysis
}

\author{
Lei Yang ${ }^{\text {aiyi Zhao }}{ }^{b}$ Shasha Zhao ${ }^{a}$ Chen Chen ${ }^{a}$ Xiaofeng Cong ${ }^{a}$ Zhi Lia \\ Meng Ren ${ }^{a}$ \\ ${ }^{a}$ Cancer Center, The First Hospital of Jilin University, Changchun, ${ }^{b}$ Department of Orthopaedics, \\ Dongzhimen Hospital, Beijing University of Chinese Medicine, Beijing, China
}

\section{Key Words}

$\mathrm{VHL} \cdot$ Promoter hypermethylation $\bullet$ Renal cell carcinoma $\bullet$ Meta-analysis

\begin{abstract}
Background/Aims: Von Hippel-Lindau gene (VHL) has been reported as a tumor-suppressor gene in some cancers. However, the association between $V H L$ promoter hypermethylation and renal cell carcinoma (RCC) remains to be clarified. We are the first to systematically integrate published papers to assess the role of hypermethylated VHL in RCC. Methods: The potential relevant papers were searched via PubMed, Embase, EBSCO, CNKI, and Wanfang databases. The overall odds ratio (OR) and corresponding 95\% confidence interval (95\% CI) were calculated to evaluate the relationship between $\mathrm{VHL}$ promoter hypermethylation and RCC. Results: Finally, a total of 1,998 RCC patients and 294 controls from 13 eligible articles were included in this meta-analysis. Under the fixed-effects model, the pooled OR from seven studies including 596 RCC and 294 nonmalignant samples showed that VHL promoter hypermethylation was significantly higher in cancer than in controls (OR $=7.93,95 \% \mathrm{CI}=2.84-$ $22.15, P<0.001)$. Subgroup analysis based on ethnic population and testing method revealed that hypermethylated $V H L$ had a significantly similar OR value in different races and detection methodologies. No significant association was found between hypermethylated $V H L$ and tumor grade, tumor stage, tumor size, histological types, and lymph node status in cancer (all $P>$ 0.05). In the current study, there was no evidence of publication bias as determined by Egger's test (all $P>0.05$ ). Conclusions: In the investigated patients, VHL promoter hypermethylation, which may play an important role in carcinogenesis of RCC, is significantly associated with an increased risk of RCC. However, VHL promoter hypermethylation is not correlated with specific clinicopathological characteristics. Additional future studies are needed to confirm our results.
\end{abstract}

L. Yang and Z. Zhao are co-first authors. 


\section{Cellular Physiology Cell Physiol Biochem 2016;40:1465-1472 \begin{tabular}{l|l|l} 
and Biochemistry $\begin{array}{l}\text { DOI: 10.1159/000453198 } \\
\text { Published online: December 20, } 2016\end{array}$ & $\begin{array}{l}\text { (c) 2016 The Author(s). Published by S. Karger AG, Basel } \\
\text { www.karger.com/cpb }\end{array}$
\end{tabular} \\ Yang et al.: VHL Promoter and Renal Cell Carcinoma}

\section{Introduction}

Renal cell carcinoma (RCC) is the second common cancer after bladder cancer in urinary system malignant tumors, accounting for approximately 62,700 new cases diagnosed, with approximately 14,240 deaths annually in the United States in 2016 [1]. Reportedly, RCC has several histological types, the most common histotypes of whose consist of clear cell RCC (ccRCC) representing 75\% of the cases, papillary RCC (pRCC) in 10\% of the cases, and chromophobe RCC constituting 5\% of the cases, [2]. Generally, RCC is asymptomatic in its early stages, and more than $50 \%$ of RCCs are detected incidentally by examinations, such as ultrasound and computed tomography (CT). Approximately $25 \%-30 \%$ of the patients with RCC are defined as cases with advanced or metastatic RCC, and the 5-year survival rate is only $12.3 \%[3]$.

Numerous genetic and epigenetic changes are involved in the pathogenesis of renal cancer [4-6]. DNA methylation, an important mechanism of epigenetic alterations, plays a key role in the regulation of gene expression and cancer development $[7,8]$. Hypermethylation of the promoter region of tumor-suppressor genes (TSG) and hypomethylation of oncogenes are common events in cancer [9-11]. Von Hippel-Lindau gene (VHL), a tumor-suppressor gene, is mapped at chromosome 3p25-26 [12]. VHL gene encodes a protein, pVHL, consisting of 213 amino acid residues [13]. It is noteworthy that as a multifunctional protein, pVHL has a close connection with the pathogenesis of familial and sporadic RCC, which is related to its role in the polyubiquitination process [14]. Moreover, due to somatic mutations or promoter methylation, the expression of pVHL is exceedingly common in kidney cancer [15].

However, the statistical power of individual studies with a small sample size remains limited. Therefore, for the first time, we conducted a systematic meta-analysis comprising an extensive number of studies to further identify the association between VHL promoter hypermethylation and RCC pathogenesis. In addition, we also evaluated the correlation of $V H L$ promoter hypermethylation with clinicopathological characteristics in RCC.

\section{Materials and Methods}

Literature search

All articles published up to April 26, 2016 were systematically searched using PubMed, Embase, EBSCO, CNKI, and Wanfang databases without any language restrictions. The subject and search terms strategy were as follows: (kidney OR renal) AND (cancer OR tumor OR neoplasm OR carcinoma) AND (VHL OR von Hippel-Lindau) AND (methylation OR epigene*). In addition, references from the relevant review articles published were also manually searched to identify other possible studies. Conference abstracts or case reports were excluded due to the lack of sufficient data for the current meta-analysis.

\section{Inclusion criteria}

The eligible articles were selected for analysis if they met the following inclusion criteria: (1) The patients had to be diagnosed with primary renal cancer; (2) The articles had to involve VHL gene promote hypermethylation data from tissue, blood, or urine; (3) The studies had to provide sufficient information on the frequencies of $V H L$ promoter methylation for estimation of the pooled odds ratio (OR) with $95 \%$ confidence interval (CI). If the authors reported multiple papers using the same groups of patients, only the most recent or complete paper was selected to avoid duplicate content.

\section{Data extraction}

The relevant data were extracted independently by two authors. The following information was collected for the eligible studies: surname of the first author, year of publication, original country, ethnicity, testing method, sample type, number of cases and control treatments, number of VHL promoter hypermethylation, clinical staging, tumor grade, histologic type, tumor size, and lymph node status. Lymph nodes metastases were defined as lymph node-positive status. Tumor grades of $\leq 2$ were defined as lowgrade, and tumor grades of 3-4 were defined as high-grade. Tumor stages of $\leq 2$ were referred to as early stage, whereas tumor stages of 3-4 were defined as advanced stage. 


\section{Cellular Physiology Cell Physiol Biochem 2016;40:1465-1472 \begin{tabular}{l|l|l} 
and Biochemistry & Dublished online: December 20, 2016 & $\begin{array}{l}\text { (c) 2016 The Author(s). Published by S. Karger AG, Basel } \\
\text { www.karger.com/cpb }\end{array}$
\end{tabular} \\ Yang et al.: VHL Promoter and Renal Cell Carcinoma}

Statistical analysis

Meta-analysis was conducted using the STATA software (version 12.0, Stata Corporation, College Station, TX, USA). The pooled odds ratio (OR) and corresponding 95\% confidence interval (95\% CI) were calculated to determine the correlation of VHL promoter hypermethylation with renal cancer. The Cochran's $\mathrm{Q}$ test and $I^{2}$ statistic were used to evaluate the between-study heterogeneity [16]. If the values of $I^{2}<50 \%$ and $P \geq 0.1$, representing a measure of lack of heterogeneity, the fixed-effects model was used; otherwise, the random-effects model was applied in the cases with significant heterogeneity [17, 18]. Egger's linear regression test was performed to detect the potential publication bias [19].

\section{Results}

Basic characteristics of the included studies

A total of 504 potentially relevant articles were initially identified through the searches in the electronic databases as described above, and five further studies were obtained by manual searching. The abstracts or full texts of these papers were carefully reviewed for compliance with the inclusion criteria. Eventually, thirteen eligible studies with 1,998 RCC patients and 294 controls were included in our study (Fig. 1) [20-32]. Seven of these studies, including 596 RCC patients and 294 nonmalignant samples, evaluated the association of $V H L$ promoter hypermethylation with RCC risk. In addition, eight studies, involving 967 ccRCC and 259 non-ccRCC, assessed the relationship between $V H L$ promoter hypermethylation and tumor histologic type. Other seven studies with 402 low-grade and 299 high-grade patients estimated the correlation between $V H L$ promoter hypermethylation and tumor grade. In five of the studies, including 53 lymph node-positive patients and 379 lymph node-negative patients, assessed the correlation between $V H L$ promoter hypermethylation and lymph node status. Further, three studies evaluated the association of $V H L$ promoter hypermethylation with tumor stage, and three studies investigated the relationship between VHL promoter hypermethylation and tumor size. The general characteristics of the included studies are summarized in Table 1.

Fig. 1. Flow diagram of the strategy of literature search among the associated studies.

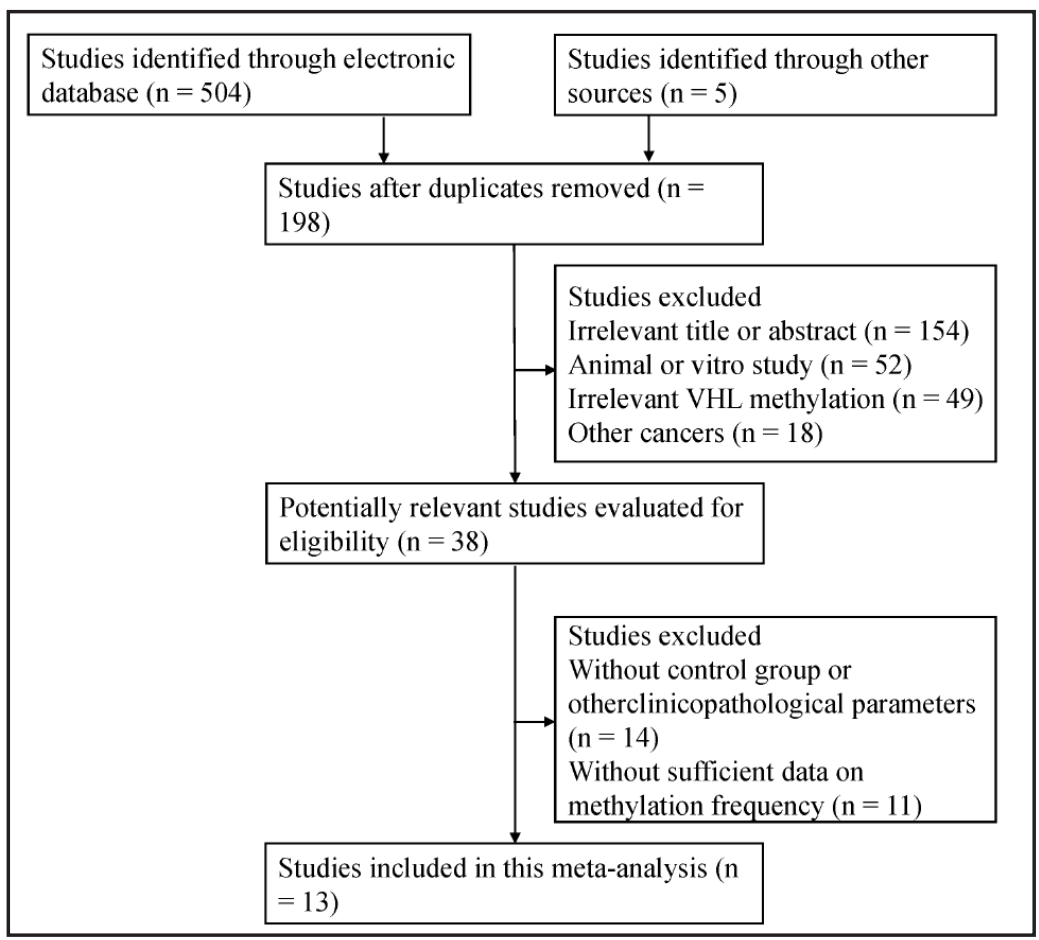


VHL hypermethylation status in RCC and control groups

No statistically significant heterogeneity was detected in the comparison of cancer vs. control groups $\left(I^{2}=0.0 \%\right.$ and $P$ $=0.859)$, and the fixed-effects model was conducted. Figure 2 depicts the VHL promoter hypermethylation status which was significantly higher in the cancer samples than in the nonmalignant samples $(\mathrm{OR}=$ $7.93,95 \% \mathrm{CI}=2.84-22.15, P<0.001$ ); seven studies with 596 RCC patients and 294 nonmalignant samples were included in the comparative analysis.

Subgroup analyses based on ethnic population (Asian population or Caucasian population) and testing method, methylation-specific polymerase chain reaction (MSP) and Non-MSP, were conducted to investigate the difference between the pooled OR in VHL promoter hypermethylation (Table 2). Our findings showed that $V H L$ promoter hypermethylation was significantly associated with RCC risk in both the Asian population and the Caucasian population, with a similar OR values (OR $=7.76,95 \% \mathrm{CI}=1.75-34.43, P=0.007$ vs. $\mathrm{OR}=8.05,95 \% \mathrm{CI}=1.98-32.74, P=0.004$, respectively). Subgroup analysis based on the testing method suggested that MSP detection and Non-MSP were susceptible to hypermethylated $V H L$, with similar OR values $(\mathrm{OR}=7.91,95 \% \mathrm{CI}=1.83-34.28, P$ $=0.006$ vs. $\mathrm{OR}=7.95,95 \% \mathrm{CI}=1.89-33.50$, $P=0.005$, respectively).

Correlation of VHL hypermethylation with clinicopathological characteristics The association of $V H L$ promoter hypermethylation and clinicopathological characteristics was further determined to evaluate the clinical significance of $V H L$ promoter hypermethylation (Table 2). In the cases without significant heterogeneity, the fixed-effects model was used in relation to tumor grade, lymph node status, tumor size, and clinical staging $\left(I^{2}=14.1 \%\right.$, $P=0.322 ; I^{2}=0.0 \%, P=0.736 ; I^{2}=0.0 \%$, $P=0.853 ; I^{2}=0.0 \%, P=0.763$, respectively). Substantial heterogeneity related to the tumor histotype $\left(I^{2}=58.0 \%\right.$ and $\left.P=0.020\right)$ was found in the cases of cancer; thus, the random-effects model was employed in these conditions.

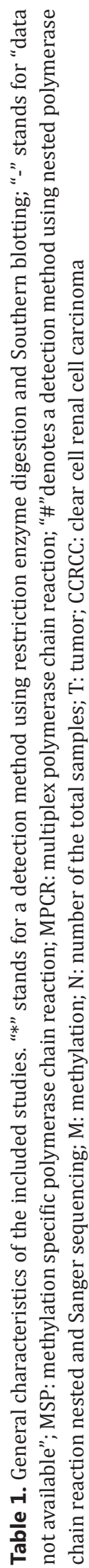

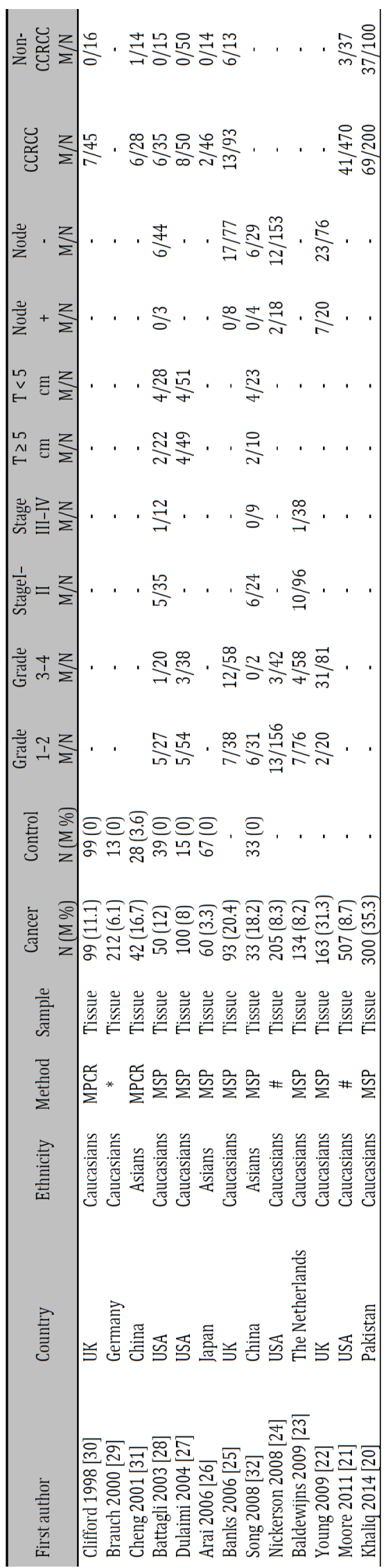




\section{Cellular Physiology Cell Physiol Biochem 2016;40:1465-1472

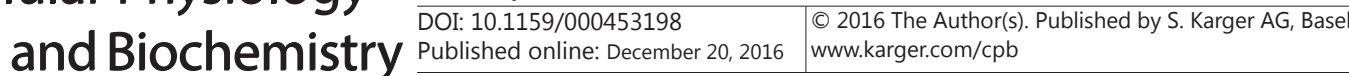

Fig. 2. The pooled OR showing the association between $V H L$ promoter hypermethylation and RCC in cancer vs. control group.

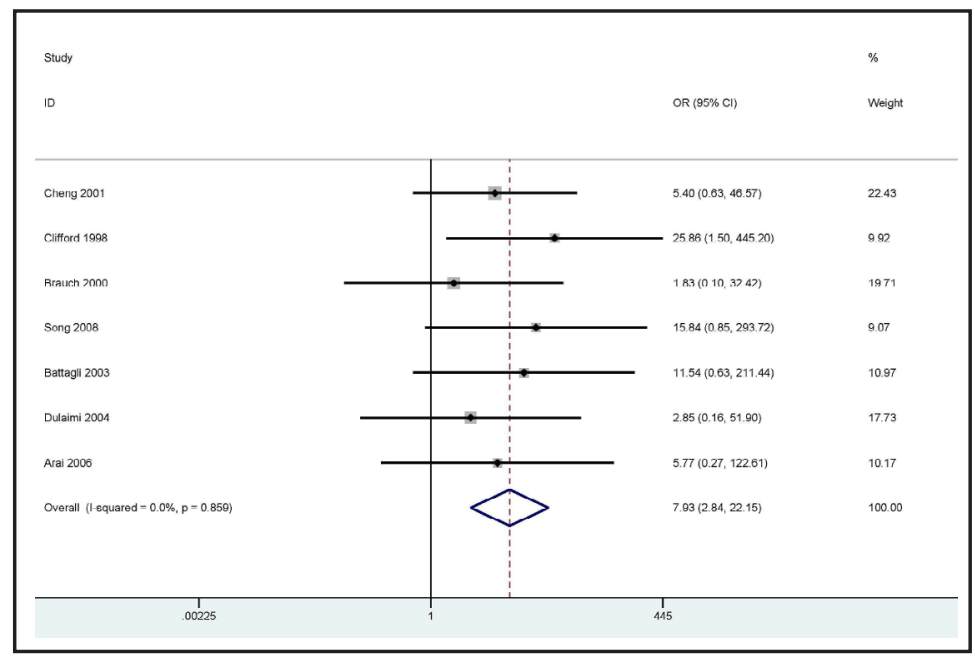

Table 2. Pooled OR of the studies evaluating VHL promoter hypermethylation. MSP: methylation specific polymerase chain reaction; T: tumor; CCRCC: clear cell renal cell carcinoma; OR: odds ratio; 95\% confidence interval $(95 \% \mathrm{CI})$

\begin{tabular}{|c|c|c|c|c|c|c|c|}
\hline & Studies & OR (95 CI \%) & $I^{2} ; p$ & P value & Cases & Controls & $p$ (Egger's test) \\
\hline Total & 7 & $7.93(2.84-22.15)$ & $0.0 \% ; 0.859$ & $<0.001$ & 596 & 294 & 0.794 \\
\hline Asians & 3 & $7.76(1.75-34.43)$ & $0.0 \% ; 0.829$ & 0.007 & 135 & 128 & \\
\hline Caucasians & 4 & $8.05(1.98-32.74)$ & $0.0 \% ; 0.528$ & 0.004 & 461 & 166 & \\
\hline Other & 3 & $7.95(1.89-33.50)$ & $0.0 \% ; 0.409$ & 0.005 & 353 & 140 & \\
\hline MSP & 4 & $7.91(1.83-34.28)$ & $0.0 \% ; 0.850$ & 0.006 & 243 & 154 & \\
\hline Clinicopathological features & & & & \multicolumn{4}{|c|}{ Cancer patients } \\
\hline Tumor grade & 7 & $0.88(0.53-1.46)$ & $14.1 \% ; 0.322$ & 0.616 & $\begin{array}{c}\text { Low-grade } \\
402 \\
\text { Stagel-II }\end{array}$ & $\begin{array}{c}\text { High-grade } \\
299 \\
\text { Stage III-IV }\end{array}$ & 0.738 \\
\hline Tumor stage & 3 & $3.69(0.96-14.17)$ & $0.0 \% ; 0.763$ & 0.057 & $\begin{array}{c}155 \\
\mathrm{~T} \geq 5 \mathrm{~cm}\end{array}$ & $\begin{array}{c}59 \\
\mathrm{~T}<5 \mathrm{~cm}\end{array}$ & 0.672 \\
\hline Tumor size & 3 & $0.91(0.35-2.39)$ & $0.0 \% ; 0.853$ & 0.854 & $\begin{array}{c}81 \\
\text { CCRCC }\end{array}$ & $\begin{array}{c}102 \\
\text { Non-CCRCC }\end{array}$ & 0.837 \\
\hline Tumor histology & 8 & $1.41(0.56-3.51)$ & $58.0 \% ; 0.020$ & 0.464 & $\begin{array}{c}967 \\
\text { Node+ }\end{array}$ & $\begin{array}{c}259 \\
\text { Node- }\end{array}$ & 0.175 \\
\hline Lymph node status & 5 & $0.91(0.43-1.93)$ & $0.0 \% ; 0.736$ & 0.805 & 53 & 379 & 0.127 \\
\hline
\end{tabular}

As seen in Table 2, no significant correlation was observed between VHL promoter hypermethylation and clinicopathological features (all $P>0.05$ ).

\section{Publication bias}

Egger's test was applied to determine the possible publication bias. The results indicated the absence of statistically significant publication bias in the current meta-analysis (Table 2; all $P>0.05)$.

\section{Discussion}

CpG islands methylation of the promoter region is an important mechanism of reduction of gene expression that can cause inhibition of gene transcription [33]. The hypermethylation of tumor-suppressor genes (TSG) is significantly associated with tumor cell proliferation, cell migration, and cell invasion [34]. The condition of VHL promoter methylation has been reported in various cancers, including papillary thyroid carcinoma [35], RCC [36], and colorectal cancer [37]. However, we found that the reported frequency of VHL promoter methylation in RCC is still controversial, with a range from $0 \%$ [38] to 35.3\% [20]. Therefore, the present meta-analysis was performed to further validate the relationship between $V H L$ promoter hypermethylation and RCC.

Under a fixed-effects model, our findings combining seven published articles revealing that $V H L$ promoter hypermethylation was significantly higher in RCC than in nonmalignant controls $(\mathrm{OR}=7.9, P<0.001)$. These results suggested that $V H L$ inactivation through promoter 


\section{Cellular Physiology Cell Physiol Biochem 2016;40:1465-1472 \begin{tabular}{l|l|l|} 
DOI: 10.1159/000453198 & $\begin{array}{l}\text { C) 2016 The Author(s). Published by S. Karger AG, Basel } \\
\text { www.karger.com/cpb }\end{array}$
\end{tabular} \\ Yang et al.: VHL Promoter and Renal Cell Carcinoma}

hypermethylation may play a key role in the carcinogenesis of RCC. We also conducted subgroup analyses to investigate the difference of the pooled OR for two ethnic populations (Asians and Caucasians) and testing method (MSP and Non-MSP). The results indicated that no significant difference was present in terms of hypermethylated VHL related to method and race. According to Egger's test results, no publication bias was detected, indicating that the result was stable.

We further determined whether the VHL promoter hypermethylation status was associated with clinicopathological features. The findings of the current analysis indicate that the frequency of hypermethylated $V H L$ was similar in different tumor grades, tumor stages, tumor sizes, pathological types, and lymph node statuses, suggesting that the VHL promoter hypermethylation status was correlated with clinicopathological features. In addition, there was no evidence of publication bias as established by Egger's test, indicating that our results were reliable.

Several potential limitations are present in the present study. First, the main ethnic populations investigated were Asian and Caucasian, while other ethnicities, such as Africans, were not included in the analysis. Second, the fluid samples from cell-free DNA in the serum and plasma or urine were limited, and thus more studies will be necessary to validate the value of fluid detection in the future. Third, our research included only articles published in English or Chinese, which might have led to selection bias.

In conclusion, our study showed that $V H L$ promoter hypermethylation is significantly associated with an increased risk of RCC. In addition, no significant association was observed between hypermethylated $V H L$ and clinicopathological features. Further large-scale studies are essential to confirm the role of hypermethylated $V H L$ in tumorigenesis and its clinical significance.

\section{Disclosure Statement}

The authors declare that they have no competing or conflict of interests.

\section{References}

1 Siegel RL, Miller KD, Jemal A: Cancer statistics, 2016. CA Cancer J Clin 2016;66:7-30.

2 Muglia VF, Prando A: Renal cell carcinoma: histological classification and correlation with imaging findings. Radiol Bras 2015;48:166-174.

3 Smaletz 0: Current management and future directions in the treatment of advanced renal cell carcinoma-a latin american perspective: 10 years in review. Int Braz J Urol 2015;41:835-843.

4 Dmitriev AA, Rudenko EE, Kudryavtseva AV, Krasnov GS, Gordiyuk VV, Melnikova NV, Stakhovsky EO, Kononenko OA, Pavlova LS, Kondratieva TT, Alekseev BY, Braga EA, Senchenko VN, Kashuba VI: Epigenetic alterations of chromosome 3 revealed by NotI-microarrays in clear cell renal cell carcinoma. Biomed Res Int 2014;2014:735292.

5 Li X, Xin S, He Z, Che X, Wang J, Xiao X, Chen J, Song X: MicroRNA-21 (miR-21) post-transcriptionally downregulates tumor suppressor PDCD4 and promotes cell transformation, proliferation, and metastasis in renal cell carcinoma. Cell Physiol Biochem 2014;33:1631-1642.

6 Linehan WM: Genetic basis of kidney cancer: role of genomics for the development of disease-based therapeutics. Genome Res 2012;22:2089-2100.

7 Khan SA, Reddy D, Gupta S: Global histone post-translational modifications and cancer: Biomarkers for diagnosis, prognosis and treatment? World J Biol Chem 2015;6:333-345.

8 Carrio E, Suelves M: DNA methylation dynamics in muscle development and disease. Front Aging Neurosci 2015;7:19.

9 Franco R, Schoneveld O, Georgakilas AG, Panayiotidis MI: Oxidative stress, DNA methylation and carcinogenesis. Cancer Lett 2008;266:6-11. 


\section{Cellular Physiology Cell Physiol Biochem 2016;40:1465-1472 \begin{tabular}{l|l|l|}
\hline DOI: 10.1159/000453198 & $\begin{array}{l}\text { C) 2016 The Author(s). Published by S. Karger AG, Basel } \\
\text { www.karger.com/cpb }\end{array}$
\end{tabular} \\ Yang et al.: VHL Promoter and Renal Cell Carcinoma}

10 Corson TW, Gallie BL: One hit, two hits, three hits, more? Genomic changes in the development of retinoblastoma. Genes Chromosomes Cancer 2007;46:617-634.

11 Jones PA, Baylin SB: The fundamental role of epigenetic events in cancer. Nat Rev Genet 2002;3:415-428.

12 Chittiboina P, Lonser RR: Von Hippel-Lindau disease. Handb Clin Neurol 2015;132:139-156.

13 Iliopoulos O, Ohh M, Kaelin WG, Jr.: pVHL19 is a biologically active product of the von Hippel-Lindau gene arising from internal translation initiation. Proc Natl Acad Sci USA 1998;95:11661-11666.

14 Kaelin WG: Von Hippel-Lindau disease. Annu Rev Pathol 2007;2:145-173.

15 Shen C, Kaelin WG, Jr.: The VHL/HIF axis in clear cell renal carcinoma. Semin Cancer Biol 2013;23:18-25.

16 Coory MD: Comment on: Heterogeneity in meta-analysis should be expected and appropriately quantified. Int J Epidemiol 2010;39:932; author reply 933.

17 Higgins JP, Thompson SG, Deeks JJ, Altman DG: Measuring inconsistency in meta-analyses. BMJ 2003;327(7414):557-560.

18 DerSimonian R: Meta-analysis in the design and monitoring of clinical trials. Stat Med 1996;15:1237-1248; discussion 1249-1252.

19 Peters JL, Sutton AJ, Jones DR, Abrams KR, Rushton L: Comparison of two methods to detect publication bias in meta-analysis. JAMA 2006;295:676-680.

20 Khaliq S, Ajaz S, Firasat S, Shahid S, Hasan AS, Sultan G, Mohsin R, Hashmi A, Mubarak M, Naqvi SA, Rizvi SA, Mehdi SQ Abid A: Unique molecular alteration patterns in von Hippel-Lindau (VHL) gene in a cohort of sporadic renal cell carcinoma patients from Pakistan. Mutat Res 2014;763-764:45-52.

21 Moore LE, Nickerson ML, Brennan P, Toro JR, Jaeger E, Rinsky J, Han SS, Zaridze D, Matveev V, Janout V, Kollarova H, Bencko V, Navratilova M, Szeszenia-Dabrowska N, Mates D, Schmidt LS, Lenz P, Karami S, Linehan WM, Merino M, Chanock S, Boffetta P, Chow WH, Waldman FM, Rothman N: Von Hippel-Lindau (VHL) inactivation in sporadic clear cell renal cancer: associations with germline VHL polymorphisms and etiologic risk factors. PLoS Genet 2011;7:e1002312.

22 Young AC, Craven RA, Cohen D, Taylor C, Booth C, Harnden P, Cairns DA, Astuti D, Gregory W, Maher ER, Knowles MA, Joyce A, Selby PJ, Banks RE: Analysis of VHL Gene Alterations and their Relationship to Clinical Parameters in Sporadic Conventional Renal Cell Carcinoma. Clin Cancer Res 2009;15:7582-7592.

23 Baldewijns MM, van Vlodrop IJ, Smits KM, Vermeulen PB, Van den Eynden GG, Schot F, Roskams T, van Poppel H, van Engeland M, de Bruine AP: Different angiogenic potential in low and high grade sporadic clear cell renal cell carcinoma is not related to alterations in the von Hippel-Lindau gene. Cell Oncol 2009;31:371-382.

24 Nickerson ML, Jaeger E, Shi Y, Durocher JA, Mahurkar S, Zaridze D, Matveev V, Janout V, Kollarova H, Bencko V, Navratilova M, Szeszenia-Dabrowska N, Mates D, Mukeria A, Holcatova I, Schmidt LS, Toro JR, Karami S, Hung R, Gerard GF, Linehan WM, Merino M, Zbar B, Boffetta P, Brennan P, Rothman N, Chow WH, Waldman FM, Moore LE: Improved identification of von Hippel-Lindau gene alterations in clear cell renal tumors. Clin Cancer Res 2008;14:4726-4734.

25 Banks RE, Tirukonda P, Taylor C, Hornigold N, Astuti D, Cohen D, Maher ER, Stanley AJ, Harnden P, Joyce A, Knowles M, Selby PJ: Genetic and epigenetic analysis of von Hippel-Lindau (VHL) gene alterations and relationship with clinical variables in sporadic renal cancer. Cancer Res 2006;66:2000-2011.

26 Arai E, Kanai Y, Ushijima S, Fujimoto H, Mukai K, Hirohashi S: Regional DNA hypermethylation and DNA methyltransferase (DNMT) 1 protein overexpression in both renal tumors and corresponding nontumorous renal tissues. Int J Cancer 2006;119:288-296.

27 Dulaimi E, Ibanez de Caceres I, Uzzo RG, Al-Saleem T, Greenberg RE, Polascik TJ, Babb JS, Grizzle WE, Cairns P: Promoter hypermethylation profile of kidney cancer. Clin Cancer Res 2004;10:3972-3979.

28 Battagli C, Uzzo RG, Dulaimi E, Ibanez de Caceres I, Krassenstein R, Al-Saleem T, Greenberg RE, Cairns P: Promoter hypermethylation of tumor suppressor genes in urine from kidney cancer patients. Cancer Res 2003;63:8695-8699.

29 Brauch H, Weirich G, Brieger J, Glavac D, Rodl H, Eichinger M, Feurer M, Weidt E, Puranakanitstha C, Neuhaus C, Pomer S, Brenner W, Schirmacher P, Storkel S, Rotter M, Masera A, Gugeler N, Decker HJ: VHL alterations in human clear cell renal cell carcinoma: association with advanced tumor stage and a novel hot spot mutation. Cancer Res 2000;60:1942-1948. 


\section{Cellular Physiology Cell Physiol Biochem 2016;40:1465-1472 \begin{tabular}{l|l|l} 
DOI: 10.1159/000453198 & $\begin{array}{l}\text { O 2016 The Author(s). Published by S. Karger AG, Basel } \\
\text { www.karger.com/cpb }\end{array}$
\end{tabular} \\ Yang et al.: VHL Promoter and Renal Cell Carcinoma}

30 Clifford SC, Prowse AH, Affara NA, Buys CH, Maher ER: Inactivation of the von Hippel-Lindau (VHL) tumour suppressor gene and allelic losses at chromosome arm 3p in primary renal cell carcinoma: evidence for a VHL-independent pathway in clear cell renal tumourigenesis. Genes Chromosomes Cancer 1998;22:200209.

31 Cheng F, Zhang XB, Zhang J, Liu XH: Abnormality of VHL gene and VEGF expression in primary renal cell carcinoma. Chin J Urol 2001;22:587-590.

32 Song XS, Wang QF: The mutation and hyper-metllylation of Von Hippel-Lindau tumor-suppressor gene in tumor tissue and urine from kidney cancer patients. Chin J Exp Surg 2008;25:635-637.

33 Ibragimova I, Dulaimi E, Slifker MJ, Chen DY, Uzzo RG, Cairns P: A global profile of gene promoter methylation in treatment-naive urothelial cancer. Epigenetics 2014;9:760-773.

34 Kwon J, Park M, Kim JH, Lee HW, Kang MC, Park JH: Epigenetic regulation of the novel tumor suppressor cysteine dioxygenase 1 in esophageal squamous cell carcinoma. Tumour Biol 2015;36:7449-7456.

35 Stanojevic B, Saenko V, Todorovic L, Petrovic N, Nikolic D, Zivaljevic V, Paunovic I, Nakashima M, Yamashita S, Dzodic R: Low VHL mRNA expression is associated with more aggressive tumor features of papillary thyroid carcinoma. PLoS One 2014;9:e114511.

36 Peckova K, Grossmann P, Bulimbasic S, Sperga M, Perez Montiel D, Daum O, Rotterova P, Kokoskova B, Vesela P, Pivovarcikova K, Bauleth K, Branzovsky J, Dubova M, Hora M, Michal M, Hes O: Renal cell carcinoma with leiomyomatous stroma--further immunohistochemical and molecular genetic characteristics of unusual entity. Ann Diagn Pathol 2014;18:291-296.

37 Melson J, Li Y, Cassinotti E, Melnikov A, Boni L, Ai J, Greenspan M, Mobarhan S, Levenson V, Deng Y: Commonality and differences of methylation signatures in the plasma of patients with pancreatic cancer and colorectal cancer. Int J Cancer 2014;134:2656-2662.

38 Hamano K, Esumi M, Igarashi H, Chino K, Mochida J, Ishida, Okada K: Biallelic inactivation of the von Hippel-Lindau tumor suppressor gene in sporadic renal cell carcinoma. J Urol 2002;167:713-717. 